\title{
Photon Stimulated Desorption of Neutral Species from Aluminyen*
}

\author{
T. S. Chon \\ Broothnvea National Laborntory \\ National Synchrotron Light Source, Bldg. 725C. \\ Upton, New Yort 11973 \\ BNL -46474
DE91 017004
}

7

\section{INTRODUCTION}

Photon Stimulated Desorption of neutral species (PSD) is the major dynamic gas losit in electron synchrotroa light source. In the National Syachrotron Light Source, PSD preseated initial machioce commissioning difficulty. Sensitivity to surfece conenmiation on PSD had been experieaced during an incident of 'Somblin Oil contaminution'.

U10B-Photon Stimulated Desorption Experimeatal Station is constructed to investigate: 1 the degree of the contribution to the photon stimulated desorption (PSD) from primary photon flux and scattered secondary photon flux, 2 - the underlying mechenism for photon stimulated desorption, 3 - criteria to chose the proper beam tube material fo: funure a accelerator such as the Superconducting X-Ray Lithography Source (SXIS), Free Electron Laser (FEI), Superconducting Super Collider (SSC), Advanced Light Source (ALS)... . In this report, only photon stimulated desorption of nestral species (PSD) from aluminum with different surface treatrnents is reported to show the great poteatial for this station to investigate beam tube material selection.

General consensus on the underlying mecbanism of PSD in operating electron syachrotron light source can be found in literatures 23.4. Many attempts to elweidate the PSD mechenism fail due to either lack of experimental data or insufficient instrumeatations. With further instrumeatation and monochromator, this station is capable to shed the light on PSD woderiying mechraism.

\section{EXPERIMENTAL}

PSD experimeats are carried out in U10B beam line of the VUV ring at the NSLS. Three electrically isolated samples located 120 degrees apart on a rotating drum in the UHV chamber. Figure I-a, shows an exploriag view of experimeatal set-up of U1OB PSD Experimental Station. The main UHV vacuum chamber is mounted on the top of an aluminum platform which can be rotated $5^{\circ}$ in a borizontal plane. The station is

-Wort performed and under the auppices of U.S. DOE under contruet DE-ACO2-76CH00016." capable to be baked to $300^{\circ} \mathrm{C}$. An all metal gate valve is used so that the station can be pretreated before installation in the beam line and sample surface can be treated in- sitar in the beam line. a 5 mils titanium wire, which can be retracked from the light path, is used for in-situ glow-discharge surface trentmeat. A rotating drum, composed of high procision ball bearings and Beryllium-copper worm gears, provides a mechenism to interchange three sample positions in vacuum. After the system is evacuated to pressure less then $2 \times 10^{\circ}$ Torr, the station is theo pivoted to let sample 1 intercept the incoming photon to the maximum extent with certain uperaure seting. Figure I-b shows the general experimental lay-out. The primary photon strikes at sample 50 milliradian grazing angle and covers about 100 square centimeter. PSD vs. photon dosage start with low curreat at low dosage ( $300 \mathrm{~ms}$ or less for 4 bours) and ends up with toral dosege of 10 ampere-hours. Only quadrupole mass spectrometer is used since $\mathrm{CO}_{2}$ decomposed by Eayard-Alpert gauge has been noticed 6

\section{RESULTS \& DISCUSSION}

Table I. shows the results of PSD yield (with arbitrary units) of 6063 Aluminum with three different treatments. Al-1 is 6063 Aluminum alloy with NSLS standard cleaning treatimeot. Water PSD desorption after $150^{\circ} \mathrm{C} 48$ bours baked is an artificial fact from a minute air leak during bake-out. Al-2 is Al-1 oxygen glow dischurge treated from 1 ampere-bour in-situ after it received 10 anpero-hours photon dosages. The driwatic decrease in PSD of every species by oxygen glow-discharge implies surface plays an important role in PSD underlying mechanism. Al-3 is Al2 wetted with moisten atmosphere after it receives 10 ampere-hours photon dosage. Fig. II-a,b show the initial PSD Mass Spectra from Al-2 and Al-3 respectively. Additional bigh oxygen PSD yield as shown in Fig. II-b is believed 2 surface reaction channel stimulated by synchrotron white light created by oxygen glow-diseharge. Further investigation equipped with surface instrument is proposed.

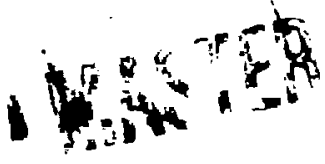




\section{DISCLAIMER}

This report was prepared as an account of work sponsored by an agency of the United States Government. Neither the United States Grvernment nor any agency thereof, nor any of their employees, makes any warranty, express or implied, or assumes any 'egel liability or responsibility for the accuracy, completeness, or usefulness of any information, apparatus, product, or process disclosed, or represents that its use would not infringe privately owned rights. Reference herein to any specific commercial product, process, or service by trade name, trademark, manufacturer, or otherwise does not necessarily constitute or imply its endorsement, recommendation, or favoring by the United States Government or any agency thereof. The views and opinions of authors expressed herein do not necessarily state or reflect those of the United States Government or any agency thereof. 


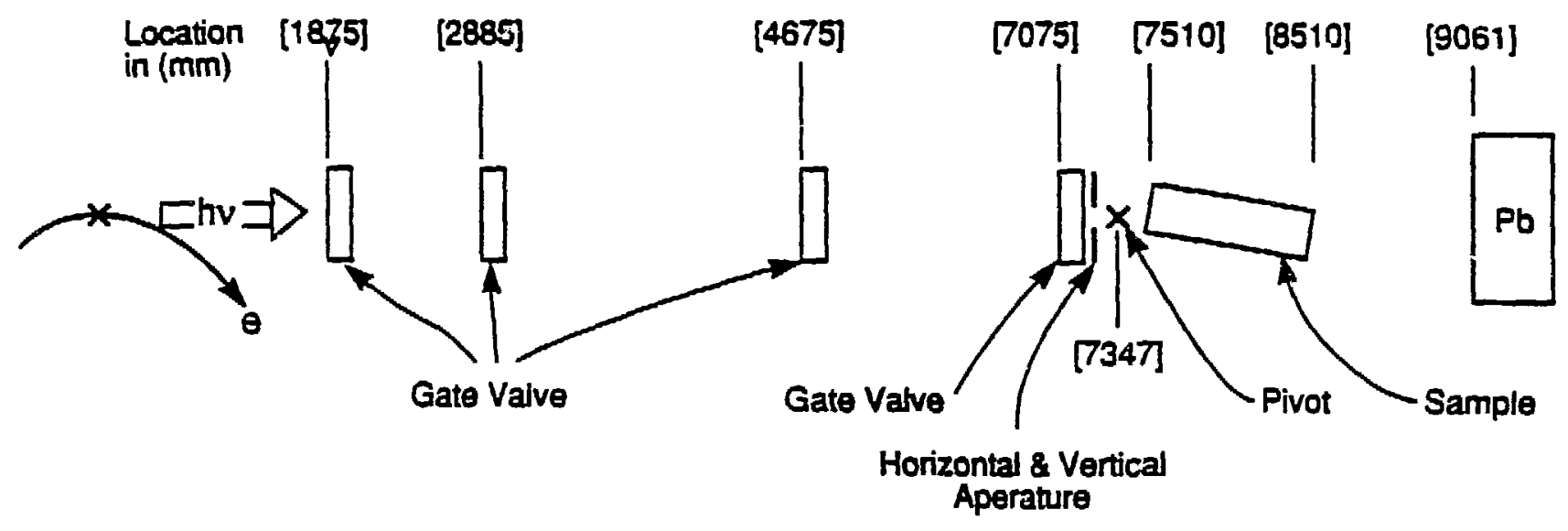

Flg. 1-b Experimental Lay-out for this Experiment at the VUV Ring of National Synchrotron Ligh Source.

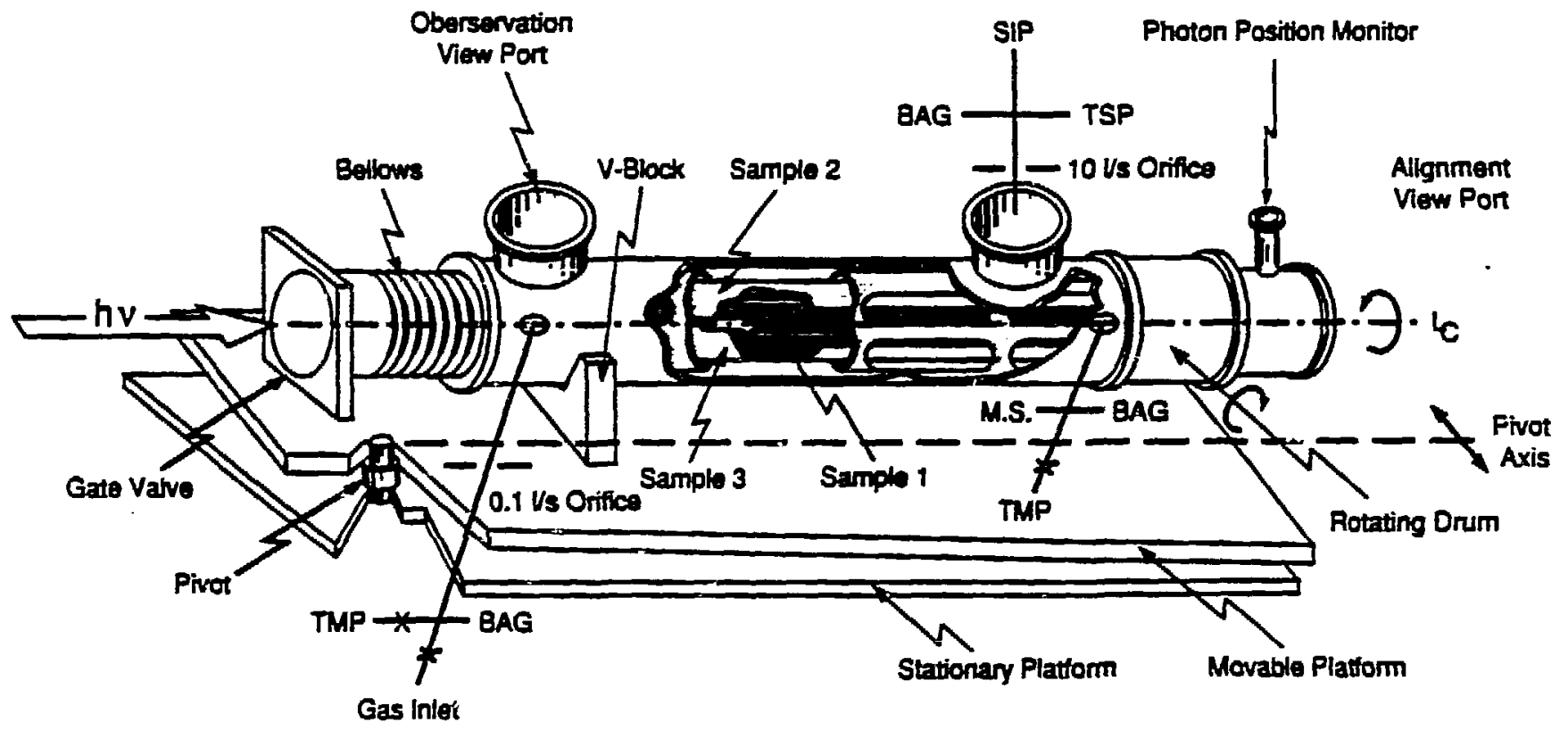

Fig. 1-a UIOB Photon Stimulated Jesorption Experimental Station

BAG: Bayard- Alpert Guage: SIP: Sputter Ion Pump; TMP: Turbomolecular Pump;

TSP: Titanium Sublimation Pump; M.S.: Ouardropole Mass Spectrometer. 


\section{ACKNOWLEDGMENT}

The andor wishes to thenk sever people who bavo contributed to this wote $\mathrm{T}$. $\mathrm{Kim}, \mathrm{M}$. Shleifer for mechenical decipen of PSD Station, G. Korm and W. deBore for experimentes.

\section{REFERENCE}

[1] T. S. Chou, H. J. Halam, 1987 IEEE Particle Accelerntor Conference, Weshington, D.C. Vol.3,p.1773, 1987

[2] E. Garwin, Stanford Linear Accelerator Ceater, Memo, 1963.

[3] O. Grobser, A. G. Mathewson, P. Strubin, E. Age and R. Souchet, J. Vac. Sci. Technol. A 7,223, 1989.

[4] M. Kobayashi, M. Mutsumoto, S. Ueda, J. Vac. Technol. AS, p.2417, 1987.

[5] T. S. Cbou, J. Vac. Technol. A (To be Published)

[6] T. S. Chou, Y. H. Gao (Private Communication)

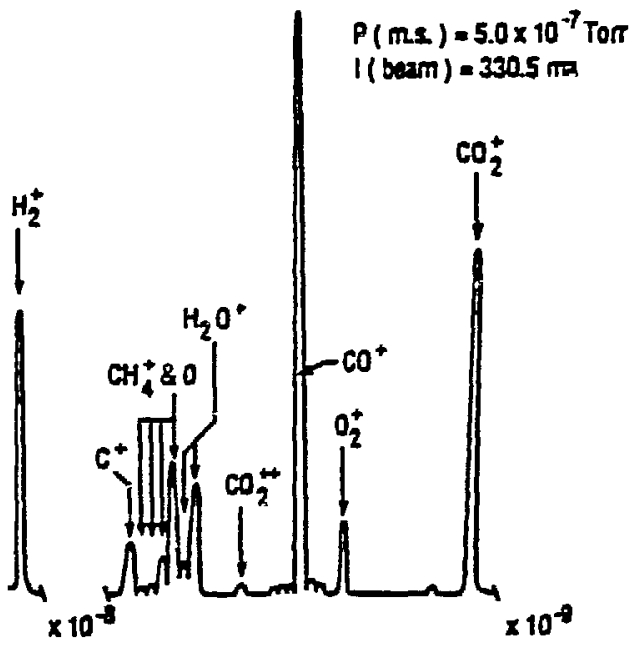

Fin II.6 The inita Photon Stmulated Desontion Mass Spectrum a 6053 aluminum taken ather two wats $\alpha$ ir expown. The ateminum samples wers theted with 1 AH oxpon gow discharged and $10 \mathrm{AH}$ symehrotren redietion.

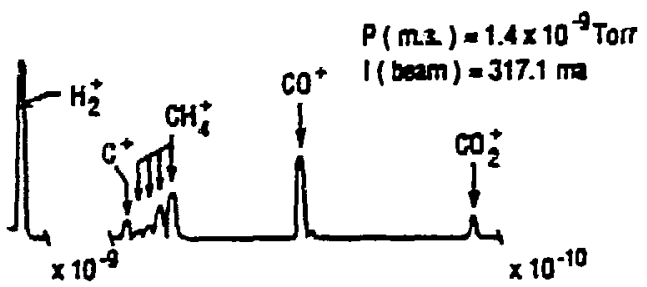

Fig. II - a The initial Phown Stimulated Decorptian Mas Spectum of 6063 aluminum tiken atter $1 \mathrm{~A}+\mathrm{f}$ oxy pen gtow diecharged treatment.
TABLE I

PHOTON STMMULATED DESORPTION

(TORR/AMP) OF

6063 ALUMNNUM

WTH DIFFERENT SURFACE IREATMENT

\begin{tabular}{|c|c|c|c|}
\hline \multirow{2}{*}{$\begin{array}{l}\text { Outguesi } \\
\text { ng } \\
\text { Species }\end{array}$} & \multicolumn{3}{|c|}{ Donage (Ampere-Hours) } \\
\hline & 0.1 & 1 & 10 \\
\hline \multicolumn{4}{|c|}{ AN-1 } \\
\hline $\mathbf{H}_{2}$ & $1.00 \times 10^{6}$ & $3.16 \times 10^{7}$ & $1.00 \times 10^{-1}$ \\
\hline $\mathrm{CH}_{4}$ & $1.24 \times 10^{4}$ & $3.03 \times 10^{-9}$ & $7.11 \times 10$ \\
\hline $\mathrm{H}_{2} \mathrm{O}$ & $2.31 \times 10^{0}$ & $5.0 \overline{\times} \times 10$ & $1.11 \times 10^{-5}$ \\
\hline co & $2.35 \times 10^{-7}$ & $5.74 \times 10^{4}$ & $1.60 \times 10^{-1}$ \\
\hline $\mathrm{C}_{2} \mathrm{H}_{4}$ & $7.74 \times 10^{\prime}$ & $1.67 \times 10^{-5}$ & ${ }_{10}^{3 .} 49 \times 10$ \\
\hline Ar & $3.24 \times 10^{-4}$ & $6.31 \times 10^{-10}$ & $1.29 \times 10$ \\
\hline \multicolumn{4}{|c|}{ AL2 } \\
\hline $\mathrm{H}_{2}$ & $1.08 \times 10^{4}$ & $4.14 \times 10^{\circ}$ & $2.15 \times 10^{-5}$ \\
\hline СH. & $5.84 \times 10^{-11}$ & $1.41 \times 10^{-4}$ & $5.01 \times 10$ \\
\hline $\mathrm{H}_{2} \mathrm{O}$ & $4.19 \times 10^{-22}$ & $1.43 \times 10^{-12}$ & $4.41 \times 10$ \\
\hline $\mathrm{CO}$ & $4.47 \times 10^{-10}$ & $1.53 \times 10^{-50}$ & $6.56 \times 10^{11}$ \\
\hline$a_{2}$ & $4.19 \times 10^{-12}$ & $1.43 \times 10^{-12}$ & $4.41 \times 10$ \\
\hline $\mathrm{CO}_{2}$ & $3.98 \times 10^{-11}$ & $7.08 \times 10^{-12}$ & $1.58 \times 10^{17}$ \\
\hline Ar & $4.19 \times 10^{-10}$ & $1.43 \times 1=-12$ & $4.41 \times 10^{-}$ \\
\hline \multicolumn{4}{|c|}{ Al-3 } \\
\hline $\mathrm{H}_{2}$ & $3.98 \times 10^{7}$ & $1.78 \times 10^{-7}$ & $6.11 \times 10^{-1}$ \\
\hline $\mathrm{CH}_{4}$ & $1.41 \times 1-\rightarrow$ & $6.31 \times 1^{-10}$ & $1.63 \times 10$ \\
\hline $\mathrm{H}_{2} \mathrm{O}$ & $298 \times 10^{4}$ & $9.26 \times 10^{-10}$ & $\frac{1}{10} .63 \times 10$ \\
\hline co & $3.55 \times 10^{2}$ & $1.45 \times 10^{2}$ & $3.55 \times 10^{-0}$ \\
\hline $\mathrm{O}_{2}$ & $1.51 \times 10^{\circ}$ & $1.18 \times 10^{4}$ & $3.98 \times 10^{-5}$ \\
\hline $\mathrm{CO}_{2}$ & $\frac{1}{4} 47 \times 10$ & $4.34 \times 10^{-0}$ & $7.50 \times 10$ \\
\hline As & ait & nil & nil \\
\hline
\end{tabular}

